\title{
Effect of Mechanical Deboning on Nutrient Quality of Chicken Meat Products
}

\author{
Marwa Mohamed A. Ibrahim; Ahmad A. M., * Yusuf M. S. and **Enas \\ Ali Kamel Mohamed \\ Dept. of Food Hygiene, *Dept. of Nutrition \& Clinical Nutrition, Faculty of \\ Vet. Med., Suez Canal University, **Dept., of Biochemistry and Nutrition, \\ Women's College, Ain Shams University
}

\begin{abstract}
Chemical properties of meat can provide beneficial information regarding the nature of mechanically deboned meat and its use in chicken meat products. Therefore, the actual nutrient profile of chicken meat products produce from mechanically deboned meat compared to hand separated meat have been studied using chemical analysis. The study analyzed 75 mechanically deboned chicken burger, luncheon and frankfurt samples for proximate chemical content. Another 25 fresh broiler carcasses was hand deboned and used as control. The average chemical composition of hand separated broiler were $72.32 \%$ moisture, $18.06 \%$ protein, $6.19 \%$ fat and $0.92 \%$ ash. There was significant differences $(P<0.05)$ in the proximate compositions between hand and mechanically deboned chicken samples. By using hand deboning of chicken carcasses, there was significant increased in moisture, protein content than mechanical deboning chicken meat products. The mean contents for calcium, phosphors and iron of hand deboned broiler carcass samples were $3.70,208.41$ and $0.32 \mathrm{mg} / 100 \mathrm{~g}$ respectively. Bone content in mechanically deboning chicken products was higher compared to hand deboned meat which clear in increasing their calcium and iron content. The results of this study challenging nutritionists for investigate the effect of higher calcium content of mechanically deboning chicken products on the public heath of consumers specially children and some critical case patients.
\end{abstract}

\section{Introduction}

Chicken meat is an important source of good quality protein and for some micronutrients such as calcium, phosphorus and iron which are not adequate in plant derived food. Consumption of chicken meat and their products is presently growing that challenge food technologists for mechanical deboning the meat to increase the production rate. Mechanically separated meat done by removing meat from flesh-bearing bones of 
chicken carcasses, resulting in the loss or modification of the meat composition (EFSA, 2013). Calcium and phosphorus in bone tissue of battery chickens is usually low when reared in commercial poultry-sheds (Canello et al., 2016). Mechanical deboning of chicken meat by grinding meat/bone together and forcing the mix through a fine screen or slotted surface to remove bone particles (Barker and Bruce, 1995). Mechanically deboned chicken meat has excellent nutritional and functional characteristics and is suitable for the formulation of various products (Fjeld, 1988 and Froning, 1981).

One of the major requirements of mechanically separated meat is the production of deboned meat without bone particles, and of calcium content which is not harmful for the consumer (Nagy et al., 2007). The normal yield of deboned meat ranges from $55 \%$ to $80 \%$ based on the part deboned and deboner settings (Mielnik et al., 2001). In Egypt, there is an abuse used of mechanical deboning machine which used in production of meat from low quality sources and chicken by-products may causes sever variation on the chemical quality of final products. In addition, the abnormal range of some microminerals may causes severe public health hazards.

A typical chicken lean meat consists of around $75 \%$ water, $20 \%$ protein, $3 \%$ fat and $2 \%$ nonprotein compounds. Proteins are the major component of the dry matter of lean meat (Briggs and Schweigert, 1990). Meat is an important source of available minerals, it is well known that absorption of dietary minerals from animal protein based meals is higher compared to wholegrain cereal based meals (King and Turnland, 1989). Macrominerals as calcium and phosphorus are required in dose of $100 \mathrm{mg}$ /day or more; whereas microminerals as iron and selenium are required in lower than 15 $\mathrm{mg}$ /day.

Phosphorus is necessary element and the second most abundant metal in the human body (Mahan and Escott-Stump, 2000). Major functions include in metabolism of human ribonucleic acid and deoxyribonucleic acid; adenosine triphosphate and phospholipid molecules. Phosphorus toxicity can result in nausea, vomiting, diarrhea, twitching, jerking, and convulsions (Obikoya, 2006).

The composition and storage strength of the final chicken meat product is affected by the raw materials used for mechanical deboning (Crosland et al., 1995). The primary need of meat composition data bases is for information on components that affect human health. This includes the proximate compistion and some trace minerals, that are associated to denoning methods (Pretorius et al., 2016). Therefore, the main goal of this study was to evaluate the main 
components of chicken meat products produce from mechanically deboned meat compared to hand separated meat using chemical analyses.

\section{Materials and Methods}

Samples Collection: A total of 75 mechanically deboned chicken meat products were purchased from different supermarkets at Isamilia city. Each 25 from chicken burger, luncheon and frankfurt samples. Another 25 fresh chicken carcasses was hand deboned and used as control and from the nearly same source of chicken used in deboned meat production.

Samples Preparation: Each carcass was prepared by removing meat with knives from close to the bone. Chicken breasts and thigh were trimmed of fat and ground with skin $(6.5 \%)$ in a chopper equipped. All chicken meat products samples were homogenized using a lab. Blender. For mineral analysis a piece from the center of the muscle part was cut out with a ceramic knife to avoid contamination with trace elements. The homogenized samples were packaged, frozen and stored at $-7^{\circ} \mathrm{C} \pm 1$ until analysis.

Chemical Analysis: The total content of moisture and ash were determined by rapid method $120^{\circ} \mathrm{C}$, 2 h (Perez-Alvarez et al., 1995). Protein and fat content of homogenized samples were determined in accordance with the $A O A C$ (1984) by a Soxtec and
Kjeltec auto distillation respectively. The homogenized samples were analyzed for calcium $(\mathrm{Ca})$, phosphorus $(\mathrm{P})$ and iron $(\mathrm{Fe})$ on ashed samples by dissolution in $\mathrm{HCl}$ and $\mathrm{H}_{2} \mathrm{SO}_{4}$ followed by atomic absorption spectroscopy (AOAC, 1990).

Statistical Analysis: Data were analyzed using Statistica v 5.0 for one-way ANOVA to identify significant differences $(\mathrm{P}<0.05)$ among samples.

\section{Results and Discussion}

Chemical properties of meat can provide beneficial information regarding the nature of mechanically deboned meat and its use in chicken meat products. Chicken carcasses and their commercial cut are often the main source of raw materials for final products of deboned chicken meat. Egyptian Organization for Standardization and Quality (EOS, 2005a) set a permissible limits for minced poultry meat-mechanically separated as follow: moisture $(70 \%)$, protein $(15 \%)$, fat $(20 \%)$, ash $(1.5 \%)$ and calcium $(5 \% \mathrm{w} / \mathrm{w})$, they not set a permissible limits for phosphorus and iron content. For chicken burger, (EOS, 2005b) the permissible limits is moisture (70\%), protein (12\%), fat (15\%) and ash $(2.5 \%)$. For luncheon chicken meat, $(\boldsymbol{E O S}, 2005 \mathrm{c})$ the permissible limits is moisture (70\%), protein $(12 \%)$, fat $(35 \%)$ and ash $(3.5 \%)$. For chicken frunkfurt (EOS, 
2005d), moisture (70\%), protein (16\%), fat (12\%) and ash (3\%).

\section{Proximate Composition of}

\section{Chicken Meat}

The content of moisture, protein, fat, and ash of $100 \mathrm{~g}$ of the hand and mechanically deboned chicken meat products are shown in table 1 . The average chemical composition of hand separated chicken meat were $72.32 \%$ moisture, $18.06 \%$ protein, $6.19 \%$ fat and $0.92 \%$ ash. The composition of chicken meat was found to be fairly constant, containing 62 to $75 \%$ water, 19 to $25 \%$ protein and around $1 \%$ ash, which is comparable with data reported by other food composition tables (Souci et al., 2000 and Swiss food composition table, 2004). Nutrient composition of the chicken meat mainly due to differences in the animals' feeding regime and breeds.

The average moisture content of chicken burger, luncheon and frankfurt were $70.77 \%, 70.50 \%$ and $69.26 \%$ respectively. The average moisture content was highest in hand deboned chicken meat samples; slightly lower in samples of mechanically deboned chicken burger and luncheon and lowest in mechanically deboned Frankfurt. Significant differences $(P<0.05)$ in moisture content of hand separated chicken meat were observed with chicken burger and luncheon. Moisture and fat contents were influenced by carcass part and to a lesser extent depended on chicken species (Mielnik et al., 2001).
According to the Egyptian Organization for Standardization and Quality (EOS, 2005a,b,c,d) permissible limits for moisture content of chicken meat, $100 \%$, $92 \%, 80 \%$ and $67 \%$ of hand separated meat, chicken burger, luncheon and frankfurt samples respectively were fit the limits.

The average protein content of chicken burger, luncheon and frankfurt were $17.06 \%, 17.81 \%$ and $17.91 \%$ respectively. The average protein content was highest in hand deboned chicken meat samples and slightly lower in samples of mechanically deboned chicken burger, luncheon and frankfurt. No significant differences $(P>0.05)$ were found between samples of chicken burger, luncheon and frankfurt for protein content. An trial done by Botka-Petrak et al., (2011) found that the content of proteins were just slightly higher $(15.57 \%)$ in deboned meat samples of chicken meat, while in samples of deboned meat of wings, back and neck these portions were $14.56 \%$, $13.46 \%$ and $14.89 \%$ respectively. According to the Egyptian Organization for Standardization and Quality (EOS, 2005a,b,c,d) permissible limits for protein content of chicken meat, $100 \%$, of all hand separated meat, chicken burger, luncheon and frankfurt samples respectively were fit the limits.

Nine of the amino acids present in proteins are essential because the human body cannot synthesize them 
from other compounds, and therefore must taken them up from food. The human requirement for protein consists of two components; (a) a requirement for the nutritionally essential amino acids, and (b) the need to meet the requirement for non-specific nitrogen in order to supply the nitrogen necessary for synthesis of the nutritionally not essential amino acids and other physiologically important nitrogen containing compounds (Pellett and Young, 1990).

Fat is the richest source of energy, essential fatty acids and precursors of compounds that regulate a number of physiological functions and helps to absorb fat-soluble vitamins. Fat is an important meat component which provides palatability and flavor to final meat products. The average fat content of chicken burger, luncheon and frankfurt were $8.97 \%, 12.83 \%$ and $13.54 \%$ respectively. The average fat content was highest in frankfurt samples slightly lower in samples of mechanically deboned chicken burger and luncheon and lowest in hand deboned broiler carcass samples. Significant differences $(P<0.05)$ in fat content of hand separated broiler were observed with all mechanically deboned chicken products. According to the Egyptian Organization for Standardization and Quality (EOS, $2005 a, b, c, d)$ permissible limits for fat content of chicken meat, $100 \%$ of hand separated meat, chicken burger and luncheon were fit the limits except only $76 \%$ of frankfurt samples were fit.

Mechanical deboning resulted in increased fat content because of the high fat in the bone marrow, which is a rich source of fat. Botka-Petrak et al. (2011) recorded that fat was highest in deboned meat of chicken backs $(20.85 \%)$, slightly lower in deboned meat chicken wings $(19.47 \%)$, and the lowest in meat samples of deboned necks (6.29\%), while in meat samples of deboned chicken carcasses it was $12.40 \%$.

The average ash content of chicken burger, luncheon and frankfurt were $2.75 \%, \quad 3.31 \%$ and $4.34 \%$ respectively. The average ash content was highest in luncheon samples slightly lower in samples of mechanically deboned chicken burger and frankfurt and lowest in hand deboned chicken meat samples. Significant differences $(P<0.05)$ in ash content of hand separated broiler samples were observed with all mechanically deboned chicken products. According to the Egyptian Organization for Standardization and Quality (EOS, 2005a,b,c,d) permissible limits for ash content of chicken meat, $100 \%, 84 \%, 68 \%$ and $64 \%$ of hand separated meat, chicken burger, luncheon and frankfurt samples respectively were fit the limits.

The lowest total ash content of chicken meat was $0.40 \%$, while these contents in deboned meat samples of back, wings and neck 
were $1.18 \%, 1.65 \%$ and $1.37 \%$, respectively (Botka-Petrak et al., 2011). Higher ash contents of mechanically deboned samples are result of bone particles incorporated into the meat. The force by mechanical pressure lead to lean away from vertebrae and through small apertures, some components probably occur in various proportions than found in hand trim. Minerals content of Chicken Meat

Meat is an important source of microelements. The range of the mean contents for calcium, phosphors and iron of hand deboned chicken meat samples were 3.70 , 208.41 and $0.32 \mathrm{mg} / 100 \mathrm{~g}$ respectively (table 2.). The average calcium content of chicken burger, luncheon and frankfurt were $7.17 \%$, $15.22 \%$ and $18.19 \% \mathrm{mg} / 100 \mathrm{~g}$ respectively. The average calcium content was highest in frankfurt samples slightly lower in samples of mechanically deboned chicken burger and luncheon and lowest in hand deboned chicken meat samples. Calcium content of chicken samples was significantly affected by deboning method, significant differences $(P<0.05)$ in calcium content of hand separated broiler samples were observed with all mechanically deboned chicken products. According to the Egyptian Organization for Standardization and Quality (EOS, 2005a) permissible limits for calcium content of chicken meat, $100 \%$ of hand separated meat were fit the limits. All samples of mechanically deboned chicken meat products were exceed the permissible limits and my cause sever public health hazards.

Higher calcium content is observed in samples of chicken neck and wing samples (Botka-Petrak et al., 2011). Calcium content is an indicator of the amount of bone in meat. The results confirmed that higher calcium content of mechanically deboned chicken meat products indicates that higher bone particles were in chicken meat products. Calcium content was the only chemical parameter that used to distinguish mechanically from non-mechanically chicken products (EFSA, 2013).

The average phosphors content of chicken burger, luncheon and frankfurt were $200.49 \%, 195.43 \%$ and $180.38 \% \mathrm{mg} / 100 \mathrm{~g}$ respectively. The mean values of phosphors content was highest in frankfurt samples slightly lower in samples of hand deboned chicken meat and mechanically deboned chicken burger and luncheon. Phosphors content of chicken samples was not significantly affected by deboning method, no significant differences $(P>0.05)$ in phosphors content of hand separated broiler samples were observed with all mechanically deboned chicken samples except frankfurt. Phosphorus is also a critical element of bones where it exists as hydroxyapatite crystals that contain a constant ratio of 
calcium to phosphate at 2:1 (Bowman and Russell, 2001).

Phosphorus in food is not considered to be a food safety or health issue (EFSA, 2013). The upper level of phosphorus intake for generally healthy individuals at 4.0 grams/day, the human daily dietary intake of phosphorus is $700 \mathrm{mg}$ for adults between the ages of 19-70 (Shils et al., 1999). Hyperphosphatemia may lead to hypocalcemia by precipitating calcium, decreasing vitamin D production, and interfering with parathyroid hormone (Bowman and Russell, 2001).

The average iron content of chicken burger, luncheon and frankfurt were $0.40 \%, 0.53 \%$ and $0.96 \% \mathrm{mg} / 100 \mathrm{~g}$ respectively. The average iron content was highest in frankfurt samples slightly lower in samples of mechanically deboned chicken burger and luncheon and lowest in hand deboned chicken meat samples.

Iron content of chicken samples was significantly affected by deboning method, significant differences $(P<$ 0.05) in iron content of hand separated broiler samples were observed with all mechanically deboned chicken products. Mechanically deboned chicken has a higher heme content than hand deboned chicken meat (Froning, 1976). Higher iron contents in mechanically deboned chicken products samples is a result of incorporation of red marrow during processing (Demos and Mondigo, 1995).

The higher levels of iron content in deboned meat may results from the iron in the bone marrow when mixed with meat. Iron is one of the most abundant elements in the earth's crust, paradoxically, iron deficiency is the common and nutritional disorder in the world (DeMaeyer and Adiels-Tegman, 1985). Due to biological iron losses, such as cyclical monthly bleeding of fertile-aged women, excessive infestation with blood-feeding parasites, or poor bioavailability of iron from plant-based diets, it is estimated that as many as $4-5$ billion people, $66-80 \%$ of the world's population, may be iron deficient (DeMaeyer \& AdielsTegman, 1985 and World Health Organization, 1992).

It could be concluded from the proximate composition of deboned chicken that hand deboning resulted higher moisture, protein content and lower fat content than mechanical deboning chicken burger, lumcheon and frankfurt. Bone content in mechanical deboning chicken was higher compared to hand deboned meat which cleared in increase their calcium and iron content. 
Table 1. Proximate composition (moisture, fat, protein and ash) of hand and mechanically deboned chicken meat products

\begin{tabular}{|c|c|c|c|c|}
\hline \multirow{2}{*}{ Samples } & Broiler & \multicolumn{3}{|c|}{ Chicken Meat Products } \\
\cline { 2 - 5 } & Meat & Burger & Luncheon & Frankfurt \\
\hline \multirow{2}{*}{ Moisture } & $72.32^{\mathrm{a}}$ & $70.77^{\mathrm{b}}$ & $70.50^{\mathrm{b}}$ & $69.26^{\mathrm{c}}$ \\
& \pm 2.15 & \pm 2.98 & \pm 3.12 & \pm 2.67 \\
\hline \multirow{2}{*}{ Protein } & $18.06^{\mathrm{a}}$ & $17.06^{\mathrm{b}}$ & $17.81^{\mathrm{b}}$ & $17.91^{\mathrm{b}}$ \\
& \pm 0.25 & \pm 0.15 & \pm 0.49 & \pm 0.09 \\
\hline \multirow{2}{*}{ Fat } & $6.19^{\mathrm{a}}$ & $8.97^{\mathrm{b}}$ & $12.83^{\mathrm{c}}$ & $13.54^{\mathrm{d}}$ \\
& \pm 0.21 & \pm 0.49 & \pm 1.04 & \pm 1.15 \\
\hline \multirow{2}{*}{ Ash } & $0.92^{\mathrm{a}}$ & $2.75^{\mathrm{b}}$ & $3.31^{\mathrm{c}}$ & $4.34^{\mathrm{b}}$ \\
& \pm 0.13 & \pm 0.58 & \pm 0.95 & \pm 1.52 \\
\hline
\end{tabular}

$* \pm$ S.E. means standard error.

Mean in the same line with different letter are significantly difference $(\mathrm{P}<0.05)$

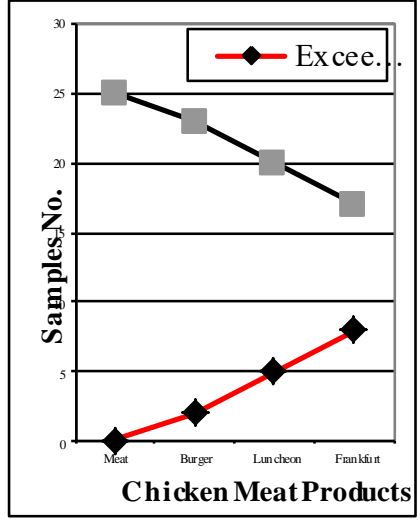

Figure 1. Moisture results of chicken meat compared to Egyptian standard

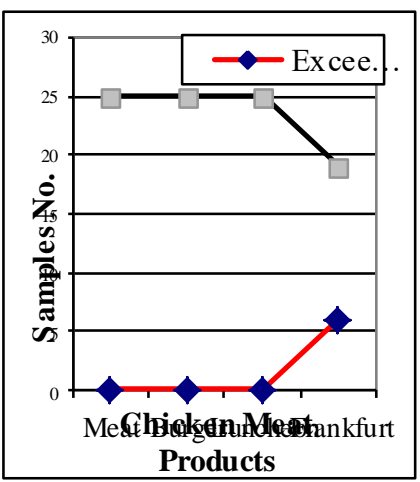

Figure 3. Fat results of chicken meat compared to Egyptian standard

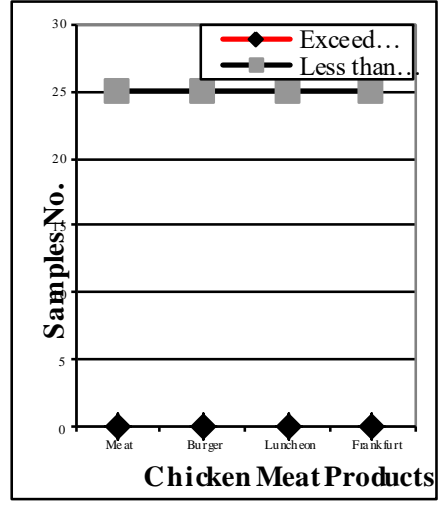

Figure 2. Protein results of chicken meat compared to Egyptian standard

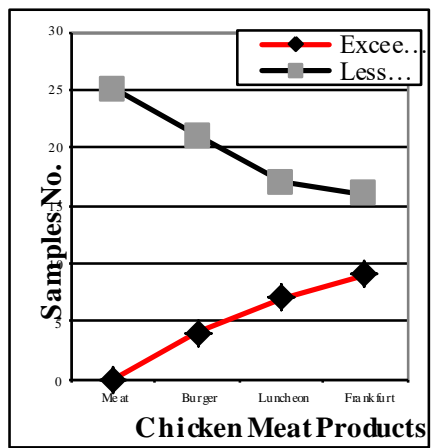

Figure 4. Ash results of chicken meat compared to Egyptian standard 
Table 2. Some minerals content of hand and mechanically deboned chicken meat products $(\mathrm{mg} / \mathrm{lo0g})$

\begin{tabular}{|c|c|c|c|c|}
\hline \multirow{2}{*}{ Samples } & Broiler & \multicolumn{3}{|c|}{ Chicken Meat Products } \\
\cline { 2 - 5 } & Meat & Burger & Luncheon & Frankfurt \\
\hline \multirow{2}{*}{ Calcium } & $3.70^{\mathrm{a}}$ & $7.17^{\mathrm{a}}$ & $15.22^{\mathrm{b}}$ & $18.19^{\mathrm{c}}$ \\
& \pm 0.82 & \pm 0.57 & \pm 1.07 & \pm 2.04 \\
\hline \multirow{2}{*}{ Phosphors } & $208.41^{\mathrm{a}}$ & $200.49^{\mathrm{a}}$ & $195.43^{\mathrm{a}}$ & $180.38^{\mathrm{b}}$ \\
& \pm 13.01 & \pm 16.01 & \pm 18.01 & \pm 10.01 \\
\hline \multirow{2}{*}{ Iron } & $0.32^{\mathrm{a}}$ & $0.40^{\mathrm{a}}$ & $0.53^{\mathrm{b}}$ & $0.96^{\mathrm{c}}$ \\
& \pm 0.06 & \pm 0.09 & \pm 0.08 & \pm 0.07 \\
\hline
\end{tabular}

$* \pm$ S.E. means standard error.

Mean in the same line with different letter are significantly difference $(\mathrm{P}<0.05)$

\section{References}

AOAC (1984): Official methods of analysis. $12^{\text {th }}$ ed., Washington DC, USA: Association of Official Analytical Chemists.

AOAC (1990): Official Methods of Analysis Association of Analytical Chemists. $15^{\text {th }}$ ed., Washington DC. Barker, R.C. and Bruce, C.A. (1995): Further processing of poultry. In: Mead, G.C. Ed. Processing of Poultry. Chapman and Hall, London, 251-282.

Botka-Petrak, K.; Hast, A; Lucic, H.; Gottstein, Z.; Gomerčić1, M.; Jakšić, S. and Petrak, T. (2011): Histological and chemical characteristics of mechanically deboned meat of broiler chickens. Veterinarski Arhiv, 81, 2: 273-283. Bowman, B., and Russell, M. (2001): Present knowledge in nutrition. Washington DC: International Life Sciences Institute.
Briggs, G.M. and Schweigert, B.S. (1990): An overview of meat in the diet. In A.M. Pearson, \& T.R. Dutson, Advances in Meat Research 6, 1-18. New York: Elsevier Applied Science.

Canello, S.; Gasparini, G.; Luisetto, P.; Di Cerbo, A. and Fabio Pomerri, F. (2016): Bone computed tomography mineral content evaluation in chickens: effects of substances in homeopathic concentration. Homeopathy, 105, 1: 92-95.

Crosland, A.R.; Patterson, R.L.S.; Higman, R.C.; Steward, C.A. and Hargin, K.D. (1995): Investigation of methods to detect mechanically recovered meat in meat products. I. Chemical composition. Meat Science, 40, 289 $-302$.

DeMaeyer, E.M., and AdielsTegman, M. (1985): The prevalence of anaemia in the world. 
World Health Statistics Quarterly, 38, 302-316.

Demos, B.P. and Mandigo, R.W. (1995): Composition and chemistry of mechanically recovered beef neck $Đ$ bone lean. J. Food. Sci.; 60: 576-579.

\section{EFSA Panel on Biological} Hazards (2013): Scientific Opinion on the public health hazards to be covered by inspection of meat (swine). EFSA J., 11, 3: 3137.

EOS (2005a): Egyptian Standards, Minced poultry meat-mechanically separated. Egyptian Organization for Standardization and Quality No. 4178, Codex: 32/1989.

EOS (2005b): Egyptian Standards, chicken luncheon. Egyptian Organization for Standardization and Quality No. 1696, Codex: $89 / 1981$.

EOS (2005c): Egyptian Standards, Minced poultry meat-mechanically separated. Egyptian Organization for Standardization and Quality No. 4178.

EOS (2005d): Egyptian Standards, Thermally treated chicken products. Egyptian Organization for Standardization and Quality No. 3493, Codex: 32/1989.

Fjeld, R.A. (1988): Mechanically separated meat, poultry and fish. In A. M. Pearson, \& T. R. Dutson (Eds.), Edible meat by-products (pp. 83-126). Barking, Essex, UK: Elsevier Applied Science.

Food and Nutrition Board of the Institute of Medicine (1997): Food and nutrition board. Dietary reference intakes: Calcium, phosphorus, magnesium, vitamin $\mathrm{D}$, and fluoride. Washington, DC: National Academy Press.

Froning, G. (1976): Mechanicallydeboned poultry meat. Food Technology, 30, 9, 50-63.

Gerber, N. (2007): The role of meat in human nutrition for the supply with nutrients, particularly functional long-chain n-3 fatty acids. Doctor of Sciences, ETH ZURICH, DISS. ETH NO. 17232,

Kempi, V.; Karkkainen, M. and Lamberg-Allardt, C. (2006): High phosphorus intakes acutely and negatively affect $\mathrm{Ca}$ and bone metabolism in a dosedependent manner in healthy young females. British Journal ofNutrition, 3,545 552.

King, J.C, and Turnlund, J.R. (1989): Human zinc requirements. Dietary pattern and zinc supply. In C.F. Mills, Zinc in Human Biology (pp. 351-363). Laufen: Springer Verlag.

Mahan, K. and Escort-Stump S. (2000): Food, nutrition, and diet therapy. Philadelphia, W.B. Saunders Company

Mielnik, M.B.; Aaby, K.; Rolfen, K.; Ellekjaer, M. and Nilsson, A. (2001): Quality of comminuted sausage formulated from mechanically deboned poultry meat. Meat Science, 61, 73-84.

Nagý, J.; Lenhardt, L.; Korimová, L.; Dičáková, Z.; Popelka, P.; Pipová, M. and I. Tomková, L. (2007): Comparison of the quality of mechanically deboned poultry meat after different 
methods of separation. Meso 9, 9295.

Obikoya, G. (2006): The benefits of phosphorus. Retrieved January 1, 2007, from http://www.vitaminsnutrition.orglvitamins/phosphorus.h tml.

Pellett, P.L., and Young, V.R. (1990): Role of meat as a source of protein and essential amino acids in human protein nutrition. In A.M. Pearson, \& T.R. Dutson, Advances in meat research 6, 329-370. New York: Elsevier Applied Science.

Perez-Alvarez, J.; Paga'nMoreno, M.; Gago-Gago, M.; Perlo, F.; Rosmini, M.; SayasBarbera', E. (1995): Manual de pra' cticas de industrias ca' rnicas (pp. 323). Reproval, Valencia, Dep.Legal V-1018- 1995.

Pretorius, B.; Schönfeldt, H. and Hall, N. (2016): Total and haem iron content lean meat cuts and the contribution to the diet. Food Chemistry, 193: 97-101.
Shils, M.; Olson, J.; Shike, M. and Ross, A. (1999): Modem nutrition and health disease. Baltimore: Williams \& Wilkins.

Souci, S.W.; Fachmann, W. and Kraut, H. (2000): Food Composition and Nutrition Tables, $6^{\text {th }}$ edition. Medpharm Stuttgart, Germany.

Swiss Food Composition Table (2004): Schweizer Nährwerttabelle für Konsumentinnen und Konsumenten. Schweizerische Gesellschaft für Ernährung, Bern; Bundesamt für Gesundheit BAG, Bern; Eidgenössische Technische Hochschule ETH, Zürich.

World Health Organisation (WHO) (1992): Iron deficiency anemia. Assessment, prevention and control. A guide for programme managers. United Nations Children Fund, United Nations University and World Helath Organisation. WHO/NHD/01.3. 


\section{تأثير نزع العظم ميكانيكيا علي الجودة الغذائية لمنتجات الاجاج}

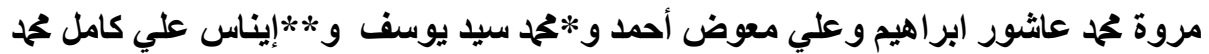

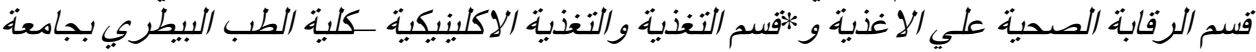

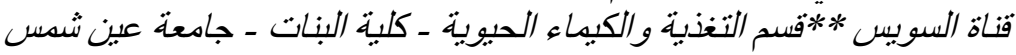

\section{الملخص العربي}

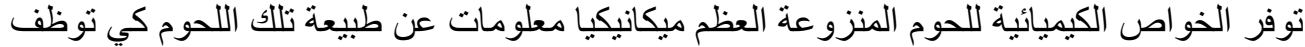

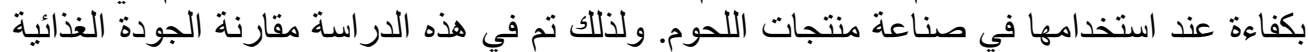

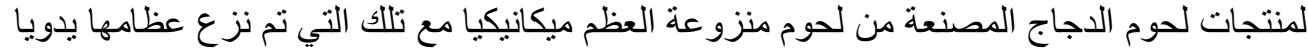

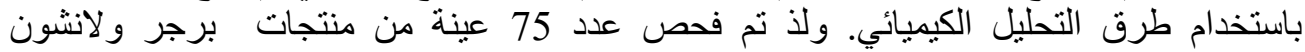

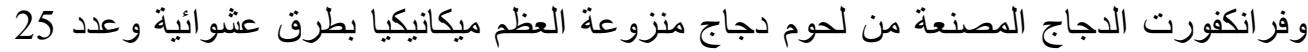

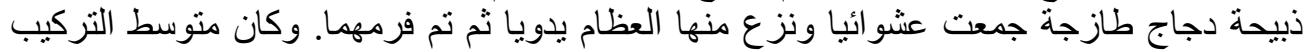

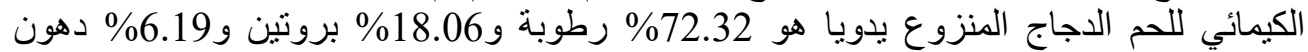
و0.92\% رماد. واوضحت الدر اسة انه هنالك فروق ذات دواتلاتلة إحصائية في التر اكيب الكيميائية بين

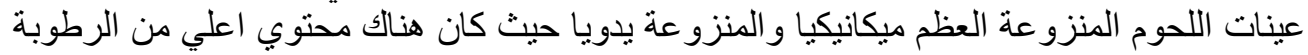

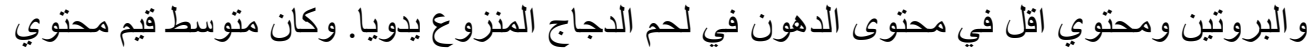

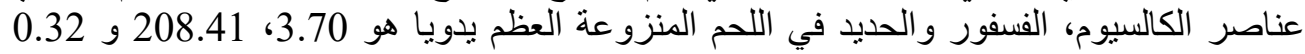

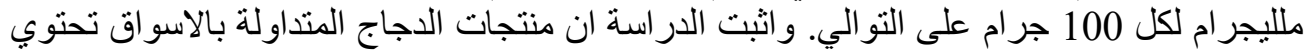

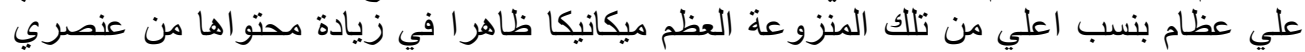

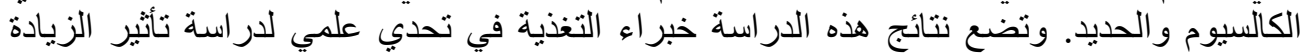

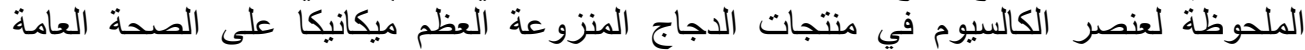
للمستهلكين خاصة الأطفال وبعض مرضئ فئى الحالات الحرجة. 